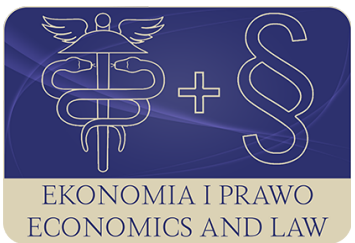

EKONOMIA I PRAWO. ECONOMICS AND LAW

Volume 20, Issue 1, March 2021

p-ISSN 1898-2255, e-ISSN 2392-1625

www.economicsandlaw.pl

ORIGINAL ARTICLE

received 18.11.2020; revised 20.03.2021; accepted 31.03.2021

Citation: Dziadkiewicz, M. (2021). Non-financial goals of municipal Social Housing Associations in managing the communal housing system. Ekonomia i Prawo. Economics and Law, 20(1): 79-89. doi:10.12775/EiP.2021.005.

\title{
Non-financial goals of municipal Social Housing Associations in managing the communal housing system
}

\author{
MICHAE DZIADKIEWICZ \\ Częstochowa University of Technology, Faculty of Management, Department of Logistics \\ and International Management, ul. Armii Krajowej 19b, 42-200 Częstochowa, Poland \\ $\square$ michal.dziadkiewicz@pcz.pl \\ (DD) orcid.org/0000-0001-5450-1669
}

\begin{abstract}
Motivation: Social rental housing is an important sector of the housing system aimed at meeting the housing needs of people whose economic strength does not allow them to purchase or rent real estate on the free market, and who at the same time do not qualify for social assistance in the form of the right to rent a municipal flat. In Poland, Social Housing Associations (hereinafter: SHAs; abbreviated and known in Poland as TBS) are the institutional form of this construction industry. SHAs, which are established by municipalities, play an important role in shaping the housing policy thanks to institutional possibilities allowing for the construction and renting of apartments, real estate management on the basis of commission contracts, or acting as a substitute investor.

Aim: The aim of the article is to analyse the assumptions of the activities of municipal SHAs. As part of the research, the types of non-financial aims in the provisions of company agreements were examined, in particular according to the criterion of their going beyond the "pure" activity of SHAs, which is the construction and operation of apartments on the basis of lease. The article identifies the optimal selection of non-financial goals covering the areas of managing the housing stock and green areas in its vicinity and managing housing communities.

Results: Thanks to the analysis of the provisions of the companies' agreements of 62 municipal SHAs, it was found that the vast majority of them had non-financial goals that allow for complementary activities in the implementation of the municipal policy. The au-

thor managed to distinguish groups of provisions that could serve the implementation
\end{abstract}


of the municipal policy in the field of housing, public property management, spatial order and greenery management.

Keywords: Social Housing Associations; non-financial goals; communal housing JEL: K15; K39; M10; M14

\section{Introduction}

On December 28, 1995, the Act on certain forms of supporting the housing construction (1995) entered into force, creating the legal basis for financing housing and social rental housing. The act created the legal framework, principles of operation and the method of collecting funds by institutional investors such as the Social Housing Associations (in Poland: TBS).

The social rental housing program was created to help municipalities meet the housing needs for those people whose economic situation does not allow them to buy a flat on the free market and whose income is so high and stable that they do not meet the criteria for housing assistance, i.e. applying for municipal premises. It should be noted that the premises built by SHAs, although they complement the housing portfolio of the municipality, do not belong to the municipal housing stock - Art. 2(1) point 10 of the Act on the protection of the rights of tenants, the municipal housing stock and amending the Civil Code (2001).

The stability of the program, existing for many years, made the municipalities willing to set up companies running SHAs, and according to the data for 2018, the companies are present in 248 localities (Muziol-Węclawowicz \& Nowak, 2018, p. 22).

It should also be noted that along with the development of their own activities, SHAs began to manage the growing infrastructure incorporated into the urban fabric. A common model is also when municipalities create companies that simultaneously run SHAs and manage the housing stock of the municipality as well as the buildings of housing communities.

The purpose of this article is to demonstrate that SHAs can achieve non-financial goals complementary to the tasks of the municipality in the field of construction and maintenance of communal housing and housing stock management, which leads to the implications of improving the quality of housing offered by the municipality and improving the quality of common space (areas surrounding residential buildings) as well as green areas used by residents.

The article describes a research gap that covers the issues of selecting and defining non-financial goals in the contracts of SHA companies and their impact on residential buildings managed by SHAs, as well as the possible implications of introducing non-financial measures in order to achieve management goals. The article indicates the optimal selection of non-financial goals for SHAs, covering the area of managing the municipal housing stock, managing housing communities and managing green areas around SHAs' buildings, as well as their social implications. 


\section{Non-financial information: literature review}

The ability to define potential non-financial goals that may be adopted by municipal resource managers requires consideration of the concept of non-financial information. Defining this concept will allow to create a measure of non-financial goal achievement that is clear to other trading participants.

Currently, it is assumed that there is no uniform definition of non-financial information, therefore it is necessary to define this concept in advance for the purposes of further discourse (Bek-Gaik \& Krasodomska, 2018, p. 26; Sobczyk, 2017, p. 397). It can be assumed that non-financial information could be understood as those descriptions, facts and opinions, i.e. qualitative data, that are difficult to express in a monetary measure or that are expressed in a measure other than money - e.g. the mission, vision or strategy of the enterprise (Gernon \& Meek, 2011).

According to Maj (2018) another helpful thing in determining the concept of non-financial information is the content of Directive of the European Parliament and of the Council on disclosure of non-financial and diversity information by certain large undertakings and groups (2014) and the EU Commission's guidelines on non-financial reporting (methodology for reporting non-financial information) (2017). The literature accepted the need to regulate the concept of non-financial information in order to ensure its quality and comparability (Monciardini, 2016; Venturelli et al., 2017).

The aforementioned directive introduced amendments to Directive on the annual financial statements, consolidated financial statements and related reports of certain types of undertakings (2013) by adding Art. 19a). Non-financial information has been defined as: “(...) information to the extent necessary for an understanding of the undertaking's development, performance, position and impact of its activity, relating to, as a minimum, environmental, social and employee matters, respect for human rights, anti-corruption and bribery matters (...), including:

- a brief description of the undertaking's business model;

- a description of the policies pursued by the undertaking in relation to those matters, including due diligence processes implemented;

- the outcome of those policies;

- the principal risks related to those matters linked to the undertaking's operations including, where relevant and proportionate, its business relationships, products or services which are likely to cause adverse impacts in those areas, and how the undertaking manages those risks;

- non-financial key performance indicators relevant to the particular business".

Taking into account the specificity of the activity of the municipal housing stock's managing entity, in order to determine the content of the concept of non-financial information, it will be helpful to refer to the concept of the municipality's own tasks defined by the Act on municipal self-government (1990). 
Article 7(1) of the aforementioned act states that the municipality's own task is to satisfy the collective needs of the community, therefore it contains a definition of own tasks. The normative construction is based on this general formulation and an open catalogue of own tasks listed in the provision in question. The concept of collective needs of a community should be associated with the public interest related to this community. It is a vague concept and its full meaning can be determined on the basis of specific circumstances. Of course, the tasks of the municipality may also be imposed on it by other acts and in the form of tasks commissioned from the scope of government administration.

Thus, the non-financial information of the entity managing the municipal resource can be defined as a derivative of the implementation of a task related to meeting the individual needs of the residential community of the municipality, and more precisely, the obligation to ensure conditions for satisfying the housing needs of a local government community, i.e. a housing environment in which the right to housing will be fulfilled (Chaciński, 2019). Gathering non-financial information is essential for gaining knowledge on the degree of implementation of the strategy adopted by it (Świerk, 2015, p. 599).

Obviously, the question arises how to determine whether such a task is being carried out and how to find that the possibility of determining and measuring the implementation of the degree of satisfaction of housing needs requires the collection of relevant non-financial information (measures), which will enable the determination of the current state and the "trend" - comparison of subsequent reporting periods - for example years.

Modern local government has to adapt the performance evaluation system to the management system, taking into account also the perspective of the inhabitants; therefore, the inclusion of non-financial information (indicators) is essential (Kowalczyk, 2018, p. 7; Skoczylas, 2011, p. 236; Świderek, 2012).

\section{Non-financial goals as provisions of the agreement of the company which runs SHAs}

In the light of the Act on certain forms of supporting the housing construction (1995), a Social Housing Association is an organizational, legal and financial form of implementation by municipal governments of construction investments aimed at meeting the housing needs of a specific population (Doliwa, 2015). SHAs may be run in the form of a limited liability company, joint stock company or a cooperative of legal persons - Art. 23 of the Act on certain forms of supporting the housing construction (1995). In practice, the most popular way of running the association is the form of a limited liability company.

According to Art. 151 of the Commercial companies code (2000), a limited liability company can be created for any legally permissible purpose, therefore not only for an economic purpose, for example, it may be a charity, public utility or sports purpose. The purpose of the company for which it is established is an important feature of the company agreement (Jara, 2020). 
Formally, SHA's premises are not included in the municipal housing stock, however, it is often the practice of municipalities to entrust SHA management to companies managing the municipal housing stock. SHA's premises are a complementary to municipal premises housing tissue that serves the implementation of the municipal task related to the conduct of housing construction. Municipal SHAs are therefore an element of the municipality's housing policy, and thus implement the financial and non-financial goals defined by it. Consequently, it should be considered that the main objectives of the city's housing policy and spatial order as well as the impact of SHA's buildings on the environment should be reflected in the provisions of the partnership agreement.

The possibility of including non-financial goals resulting from the municipality's housing policy in contracts of companies running SHAs also results from Art. 2 of the Municipal economy act (1996), which provides for the possibility of conducting it, among others in the form of a municipal limited liability company or a joint stock company. Municipal SHAs are therefore an example of municipal companies that carry out some of the public tasks incumbent on the municipality.

Potential legal problems with the inclusion of non-financial objectives in the contract of the company running SHAs arise from Art. 27 of the Act on certain forms of supporting the housing construction (1995), which contains an exhaustive catalogue of the association's tasks with the main goal of building residential houses and their operation on the basis of lease, which potentially limits the possibility of including other goals in the company agreement, resulting, for example, from the municipal task of spatial order and environmental protection.

At this point, however, it should be emphasized that pursuant to Art. 27 sec. 2 point 5 of this act, the society may also conduct other activities related to housing construction and accompanying infrastructure. As indicated by the Supreme Court (Resolution, 2014): "all legal actions that are auxiliary, incidental or necessary to perform the basic task of operating residential houses on the basis of lease may be treated as ,related to housing construction' and thus admissible".

\section{Methods}

During the research conducted for the purposes of this article, the author carried out an in-depth analysis of the applicable legal regulation regarding the possibility of including non-financial goals in the contracts of companies operating municipal SHAs. In addition, the jurisprudence of the courts in this regard was reviewed. Then, the views of representatives of the legal doctrine regarding the goals and possible scope of activity of the Social Housing Associations were analysed.

As part of the study, the contracts of companies that are owned by municipalities and that run the Social Housing Association (municipal TBS) were an- 
alysed. It was established that there are 248 companies of this nature operating in the country (Muzioł-Węclawowicz \& Nowak, 2018, p. 22).

For the proper conduct of the study, it was assumed that the sample size should be 60 SHAs (TBS). Finally, the content of 62 contracts of randomly selected companies was analysed. In the texts of the company agreements, provisions referring to non-financial goals that going beyond the "pure" activity of SHAs, such as the construction of residential houses and their operation on a lease basis, were identified. Due to different forms of describing the same type of non-financial goals in the content of company contracts, individual provisions were finally assigned to the types of non-financial goals defined by the needs of the study.

\section{Non-financial goals in the practice of municipal SHAs: study results}

In the analysed contracts of companies running municipal SHAs, the author searched for provisions containing non-financial goals that go beyond the "pure" activity of SHAs, which is the construction of residential houses and their operation on a lease basis.

It should be noted that in the analysed area there is a research gap covering the issues of defining and assessing the legitimacy of setting individual non-financial goals for SHAs. In particular, there are no coherent definitions of individual goals and objective measures of their achievement. However, the analysis of the available research material allows us to conclude that setting non-financial goals as part of management goals leads to positive results in terms of improving the quality of the housing stock, improving the quality of the space surrounding residential buildings and, last but not least, improving the quality of green areas.

Taking into account the indicated gap in defining non-financial goals of the SHA, they have been grouped into the following issues. The first group includes provisions enabling the municipal SHAs to undertake activities complementary to the municipality ,s task of creating and managing the municipal housing stock. As it has already been mentioned, the housing stock of SHAs is not part of the housing stock of the municipality, however, due to the business model, the municipal SHAs can perform a number of activities complementing the activities of the municipality in the field of housing stock management. This group includes provisions of agreements imposing on companies the obligation to implement the housing policy of municipalities, improve the quality of the city's housing stock, perform the function of a substitute investor in the field of housing construction with accompanying infrastructure, and, last but not least, renovate and modernize those apartments that are not owned by rental companies.

The second group includes provisions regarding the possibility of maintaining or building public utility buildings other than residential as well as the construction and maintenance of infrastructure accompanying residential buildings. 
The next group includes provisions regarding the possibility of managing residential and non-residential real estate based on contracts of mandate. In practice, these provisions allow for the management of buildings of housing communities of which the municipality is a member. Establishing a joint manager of the municipality's shares in residential buildings with a housing association creates great opportunities for coordinating the municipality's policy regarding the housing tissue of the city as well as the quality of the common space between residential buildings.

The other groups also include provisions enabling the development of green spaces, facilitating mobility for job-seeking families, as well as the disposal and management of sewage and electricity generation.

Chart 1 shows the results of the companies' analysis in terms of the "pure" activity of SHAs. It turned out that only $8 \%$ of the studied entities did not have provisions regarding other non-financial purposes in their contracts.

Chart 2 shows what non-financial goals are included in the contracts of the subject companies. By far the most popular group of provisions (76\%) were those that allow real estate management on the basis of mandate contracts and thus allow the municipal SHAs to manage those housing communities of which the municipality is a member. It is also worth noting that the privatization of premises in the municipal housing stock, which had been ongoing since the 1990s, resulted in the fragmentation of ownership in municipal buildings and the necessity for municipalities to manage only shares in them. The appointment of a municipal administrator of housing communities may in some way mitigate the negative consequences of this fragmentation by obtaining the possibility of coordinating the municipality's housing policy in relations with housing communities.

Other significant groups of provisions are provisions enabling complementary activities in the implementation of the municipality's own task, which is satisfying housing needs, e.g. through the creation and management of the municipal housing stock (68\% of subjects) as well as the maintenance of public utility buildings and associated infrastructure (56\% of subjects). It should be emphasized that the company which owns the SHA's buildings can naturally complement the activities of the municipality in the implementation of housing policy and spatial order, which is often imposed by the very location of the SHA's buildings in the tissue of municipal buildings. The management of green areas can also play an important role here, as these provisions were included in the contracts of $19 \%$ of the studied entities. The municipal property manager can play a significant role in the quality of green areas between buildings, as well as, for example, as an entity that promotes ecological attitudes or attitudes towards spatial order.

A small group of entities had provisions in their company agreements to facilitate mobility for job-seeking families (13\% of subjects), sewage disposal and treatment (5\% of entities), or electricity generation (3\% of subjects). 


\section{Conclusion}

The study carried out for the purposes of this article allowed to confirm the importance of the role of municipal SHAs, whose activities may complement the policies of municipalities in the implementation of their own tasks.

The municipal company running the SHA has institutional possibilities for the complementary implementation of the municipality's policy, mainly in the scope of satisfying the housing needs of the inhabitants and spatial order. In the author's opinion, the model in which the municipality uses the possibilities of SHAs in the field of real estate management on behalf of entrusting it with the management of housing communities of which it is a member, allows for more effective implementation of its goals than in the case of outsourcing solutions. The municipality has the possibility to shape this policy on an ongoing basis thanks to the provisions in the company agreement and the management objectives set to the members of the management board under management contracts.

The analysis of the findings allowed to identify the optimal non-financial goals and their social implications. Goals consisting in supporting the management of the municipal housing stock result in the improvement of the quality of communal housing. The emphasis on the non-financial goals of the SHAs allows the management boards of these companies to be guided by criteria other than profit maximization. SHAs have an opportunity to build and shape the space around buildings using good practices as opposed to the so-called ,pathological' real estate development, which is an impulse for the primary real estate market. Examples of such housing estates include Nowe Żerniki in Wroclaw, or Nowy Nikiszowiec, built as part of the "Housing Plus" programme, in Katowice.

Including SHAs in the management of urban greenery allows the use of their institutional competences to improve the quality of green areas in the city. As an example, there are the concepts of pocket parks implemented by ZGM-TBS Częstochowa sp.z o.o. and the City Hall of Czestochowa. These companies can be a vehicle for promoting ecological attitudes and "green" solutions in the construction industry.

The conducted research allowed for the conclusion that these possibilities are noticed by the municipalities running Social Housing Associations, which results in the inclusion of the above-mentioned provisions in most company contracts. Such practice allows the implementation of the goals of the municipality's policies already in the context of the activities of the SHAs.

\section{References}

Bek-Gaik, B., \& Krasodomska, J. (2018). Informacje niefinansowe jako obszar współczesnej sprawozdawczości przedsiębiorstw: definicja, źródła i proponowane kierunki badan. Zeszyty Naukowe Uniwersytetu Ekonomicznego w Krakowie, 2(974). doi:10.15678/ZNUEK.2018.0974.0202. 
Chaciński, J. (2019). Ochrona praw lokatorów. Komentarz. Warszawa: C.H. Beck. Communication from the Commission: guidelines on non-financial reporting (methodology for reporting non-financial information) (OJ C 215, 5.7.2017).

Directive 2013/34/EU of the European Parliament and of the Council of 26 June 2013 on the annual financial statements, consolidated financial statements and related reports of certain types of undertakings, amending Directive 2006/43/EC of the European Parliament and of the Council and repealing Council Directives 78/660/EEC and 83/349/EEC (OJ L 182, 29.6.2013).

Directive 2014/95/EU of the European Parliament and of the Council of 22 October 2014 amending Directive 2013/34/EU as regards disclosure of non-financial and diversity information by certain large undertakings and groups (OJ L 330, 15.11.2014).

Doliwa, A. (2015). Prawo mieszkaniowe: komentarz. Warszawa: C.H. Beck.

Gernon, H., \& Meek, G.K. (2001). Accounting: an international perspective. London: MCGrawHill.

Jara, Z. (Ed.). (2020). Kodeks spótek handlowych: komentarz. Warszawa: C.H. Beck.

Kowalczyk, M. (2018). Mierniki niefinansowe w pomiarze dokonań jednostek samorzadu terytorialnego w Polsce. Poznań: Uniwersytet Ekonomiczny.

Maj, J. (2018). Embedding diversity in sustainability reporting. Sustainability, 10(7). doi:10.3390/sul0072487.

Monciardini, D. (2016). The 'coalition of the unlikely' driving the EU regulatory process of non-financial reporting. Social and Environmental Accountability Journal, 36(1). doi:10.1080/0969160X.2016.1149302.

Muzioł-Węcławowicz, A., Nowak, K. (Eds.). (2018). Raport o stanie polskich miast: mieszkalnictwo spoteczne. Retrieved 20.03.2021 from http://obserwatorium.miasta.pl.

Skoczylas, W. (2011). Strategiczna karta wyników w pomiarze osiągnięć jednostki samorządu terytorialnego. Zeszyty Naukowe Uniwersytetu Szczecińskiego. Finanse, Rynki Finansowe, Ubezpieczenia, 687(48).

Sobczyk, M. (2017). Zakres pojęciowy terminu "informacja niefinansowa" jako źródło zróżnicowania ujawnień niefinansowych przedsiębiorstw. Zeszyty Naukowe Uniwersytetu Szczecińskiego. Finanse, Rynki Finansowe, Ubezpieczenia, 4(88). doi:10.18276/frfu.2017.88/1-38.

Świderek, I.M. (2012). Budżet zadaniowy i strategiczna karta wyników w jednostkach samorządu terytorialnego. Gdańsk: ODDK.

Świerk, J. (2015). Pomiar dokonań jednostki samorządu terytorialnego przy wykorzystaniu strategicznej karty wyników na przykładzie gminy Inowrocław. Annales Universitatis Mariae Curie-Sktodowska. Sectio H. Oeconomia, 49(4). doi:10.17951/h.2015.49.4.589.

Uchwała Sądu Najwyższego z dnia 6 czerwca 2014 [Resolution of the Supreme Court of June 6, 2014] (III CZP 24/14) (Poland). 
Ustawa z dnia 15 września 2000 r. Kodeks spółek handlowych [Commercial companies code of September 15, 2000] (Dz.U. 2000 nr 94 poz. 1037) (Poland).

Ustawa z dnia 20 grudnia 1996 r. o gospodarce komunalnej [Municipal economy act of December 20, 1996] (Dz.U. $1997 \mathrm{nr} 9$ poz. 43) (Poland).

Ustawa z dnia 21 czerwca 2001 r. o ochronie praw lokatorów, mieszkaniowym zasobie gminy i o zmianie Kodeksu cywilnego [Act of June 21, 2021 on the protection of the rights of tenants, the municipal housing stock and amending the Civil Code] (Dz.U. 2001 nr 71 poz. 733) (Poland).

Ustawa z dnia 26 października 1995 r. o niektórych formach popierania budownictwa mieszkaniowego [Act of October 26, 1995 on certain forms of supporting the housing construction] (Dz.U. $1995 \mathrm{nr} 133$ poz. 654) (Poland).

Ustawa z dnia 8 marca 1990 r. o samorządzie gminnym [Act of March 8, 1990 on municipal self-government] (Dz.U. $1990 \mathrm{nr} 16$ poz. 95) (Poland).

Venturelli, A., Caputo F., Cosma S., Leopizzi R., \& Pizzi S., (2017), Directive 2014/95/EU: are Italian companies already compliant. Sustainability, 9(8). doi:10.3390/su9081385.

\section{Acknowledgements}

Author contributions: author has given an approval to the final version of the article.

Funding: this research was funded by the author's own sources. 


\section{Appendix}

\section{Chart 1.}

Non-financial goals of municipal SHAs going beyond "pure" activity (\%)

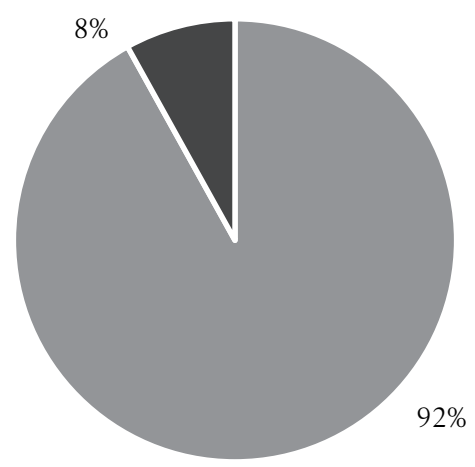

- SHAs with non-financial goals beyond "pure" activity

- SHAs with no financial goals beyond "pure" activity

Source: Own preparation.

\section{Chart 2.}

\section{Types of non-financial goals of municipal SHAs (\%)}

complementary activities in the management of the municipal housing stock

maintaining or building non-residential public buildings

possibility to manage housing communities

development of green areas

facilitating mobility for job-seeking families

sewage disposal and treatment

generation of electricity
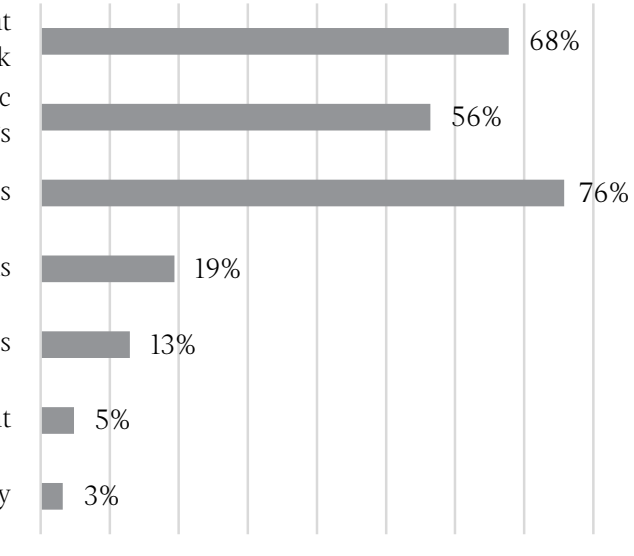

$\begin{array}{lllllllll}0 & 10 & 20 & 30 & 40 & 50 & 60 & 70 & 80\end{array}$

Source: Own preparation. 
